九州大学学術情報リポジトリ

Kyushu University Institutional Repository

Incidence of Yellow Rice Stem Borer Scirpophaga incertulas Walker in Haiphong, Vietnam and Control Efficacy of Egg Mass Removal and Insecticides

Ho, Giang Thi Thu

Department of Entomology, Hanoi University of Agriculture

Le, Cuong Viet

Plant Protection Department of Haiphong

Nguyen, Thuy Hong

Plant Protection Department of Haiphong

Ueno, Takatoshi

Laboratory of Insect Natural Enemies, Division of Biological control, Faculty of Agriculture, Kyushu University

https://doi.org/10.5109/1441362

出版情報: 九州大学大学院農学研究院紀要. 58 (2)，pp.301-306，2013-09. Faculty of Agriculture， Kyushu University

バージョン :

権利関係 : 


\title{
Incidence of Yellow Rice Stem Borer Scirpophaga incertulas Walker in Haiphong, Vietnam and Control Efficacy of Egg Mass Removal and Insecticides
}

\author{
Giang Thi Thu HO' ${ }^{1}$ Cuong Viet $\mathrm{LE}^{2}$, Thuy Hong NGUYEN ${ }^{2}$, \\ Takatoshi UENO ${ }^{3 *}$ and Dinh Van NGUYEN ${ }^{1}$
}

\author{
Laboratory of Insect Natural Enemies, Institute of Biological Control, Faculty of Agriculture, \\ Kyushu University, Fukuoka 812-8581, Japan \\ (Received April 26, 2013 and accepted May 16, 2013)
}

\begin{abstract}
The yellow rice stem borer (YRSB) Scirpophaga incertulas (Walker) is one of the most serious pests of rice in Southeast Asia. In the present study, the incidence of YRSB was surveyed in 2011 and 2012 at Anlao, a main rice growing district of Haiphong Province, Vietnam. Efficacy of removing YRSB egg masses and spraying with three insecticides was also examined. The results showed that the densities of YRSB larvae and pupae were very low in main rice-cropping times, i.e., late spring and middle summer seasons. In fact, the percentages of dead hearts and white heads were low. However, in middle summer, the density of YRSB and the percentage of damaged stems were higher than those in late spring rice. Efficacy of controlling measures was then evaluated with 11 treatments consisting of egg mass removal and insecticide applications. The results demonstrated that all measures provided better control of YRSB than the control. However, different measures resulted in different percentages of white heads. Efficacy of two newly used insecticides Virtako $40 \mathrm{WG}$ and Prevathon $5 \mathrm{SC}$ was highest when applied twice. The efficacy was followed by removal of egg mass twice, spraying Virtako 40 WG once or Prevathon $5 \mathrm{SC}$ once with and without removal of egg mass and spraying Regent $800 \mathrm{WG}$. A combination of removing egg masses and spraying Regent $800 \mathrm{WG}$ once provided a better result than spraying Regent 800 WG twice. Effective YRSB management tactics were discussed on the basis of the results obtained.
\end{abstract}

Key words: efficacy measure, rice paddies, rice pest management, white heads

\section{INTRODUCTION}

Haiphong Province, located at $20^{\circ} 46^{\prime} \mathrm{N}, 106^{\circ} 42^{\prime} \mathrm{E}$, belongs to the coastal area of the Red River Delta (RRD), North Vietnam, where the rice is the most important crop. There are two main rice-cropping times in Haiphong and RRD, i.e., spring and summer, though rice is planted in different periods in each season. For example, in spring, seeds of early spring rice are sown in December and the seedlings are transplanted in January-February while, for late spring rice, seeds are sown at the beginning of February and transplantation is made in middle to late of February. Likewise, for summer rice crop, cropping times are early, middle and late summer.

In Haiphong and RRD, late spring and middle summer rice production has been increasing in recent years because these crop times are less affected by coldness at the beginning of the year and because the flowering period of the rices occurs in suitable hot weather, making the crop yield higher and more stable than the early spring and late summer rices. Early spring rice occupies $75 \%$ of the paddy field in the spring season in 1998; however, in 2011 , it was only $15 \%$ in spring rice and the remaining $85 \%$ was late spring rice. For the summer crop, the areas of early, middle and late summer rice

1 Department of Entomology, Hanoi University of Agriculture, Vietnam

Plant Protection Department of Haiphong, Vietnam

3" Laboratory of Insect Natural Enemies, Division of Biological control, Faculty of Agriculture, Kyushu University, Fukuoka 812-8581, Japan

* Corresponding author (E-mail: ueno@grt.kyushu-u.ac.jp) crop in 1998 were $26.2 \%, 22.2 \%$ and $51.6 \%$, respectively. However, the areas of early, middle and late summer crops have changed completely and were $8.6 \% ; 87.8 \%$ and $3.6 \%$, respectively in 2011 . Such changes in rice growing periods may influence the occurrence and severity of insect pests.

In a review paper on the insect and disease pests of rice in Vietnam from 1975 onward, Dinh and Doanh (2010) recorded 17 key pests of rice. The most important pests in terms of damaged or destroyed area were brown plant hopper, the vector of the ragged stunt and grassed stunt virus, rice leaf folder, and yellow stem borer. Among the three rice pests, the current status of yellow stem borer in Haiphong Province and RDD is not well documented.

The yellow stem borer Scirpophaga incertulas (Walker) (hereafter, YRSB) is known as one of the most serious pests of rice in Southeast Asia. The larvae bore into the stem of rice plants, which results in death of terminal shoot, known as "dead heart" in the tillering or vegetative stage, or drying of panicles with unfilled grains, called "white ear" in the panicle or reproductive stage. Because of severe crop loss caused by YRSB, effective measures to manage the pest are on strong demand in Vietnam.

The current paper is dealing with the incidence of YRSB during 2011 and 2012 at Anlao District, a main growing rice district of Haiphong Province in Vientam. In addition, the efficacy of removal of egg masses and some insecticides was examined as the measures of controlling YRSB. We discuss the strategy of effective management of the pest in rice paddies. 


\section{MATERIALS AND METHODS}

\section{Experimental rice fields and monitoring YRSB}

The data were collected following the Vietnam National Technical Regulation on surveillance method of plant pests (MARD, 2010). The investigation was made once in 7 days at Anlao, Haiphong, in which three paddy fields were selected for each late spring and middle summer rice season. Rice variety selected in the present study was Bacthom 7, a susceptible variety against YRSB. Nursery was sown on $7^{\text {th }}$ July 2012 , and line transplanting was done on $30^{\text {th }}$ July 2012 . The space between rows was $18 \mathrm{~cm}$, and that between plants was $14 \mathrm{~cm}$.

In each field, 10 spots on the diagonal line of the area were set up for YRSB monitoring. The size of a study spot was $25 \mathrm{~m}^{2}(5 \mathrm{~m} \times 5 \mathrm{~m})$ and the spots were separated each other by a space of $50 \mathrm{~cm}$ without rice plants. Also, the spots were at least 2 meter apart from the field border. In each spot, 10 rice hills were monitored. All damaged stems were cut at the base of the stem and were brought to the laboratory to examine if they were damaged by YRSB or by other pests. The numbers of YRSB larvae and pupae were recorded in the laboratory. The monitoring of YRSB was conducted in 2011 and 2012.

\section{Efficacy of removal of egg mass and insecticides}

The efficacy of insecticide applications on YRSB control was investigated in 2012 using the fields mentioned above. The experimental spots were prepared based on randomized completed block design (RCBD) with three replications of 11 experiemntal treatments. Other experimental set-up was the same as above.

The eleven treatments prepared (summarized in Table 1) consisted of: removal egg masses twice (1), removal egg masses once and spraying with one of the three insecticides once (3), spraying one of the three insecticides once (3), spraying one of the three insecticides twice (3) and the control (1). Dates for the first and second pesticide application were on $25^{\text {th }}$ Sept., 2012 and on $30^{\text {th }}$ Sept. 2012, respectively. Because the initial density of YRSB egg mass could affect the outcome of the results regardless of the efficacy of any control measure, we checked the number of egg mass in the study spots. For all spots except the control, the number of egg masses was set as one egg mass $/ \mathrm{m}^{2}$; if no egg mass was found, then a rice hill with one egg mass was introduced into the spot. If there were more than one egg mass $/ \mathrm{m}^{2}$ then egg masses were removed to keep the density of one egg $\mathrm{mass} / \mathrm{m}^{2}$.

The following treatments were made: For the treatment I, the first egg-mass removal was made on $25^{\text {th }}$ Sept. and the second was done on $30^{\text {th }}$ Sept. For the treatments II, III, IV, the removal of egg masses was done on $25^{\text {th }}$ Sept. For the treatment V, VI, VII, VIII, IX X and XI, monitoring to ensure density of 1 egg mass/m2 was made in $25^{\text {"h }}$ Sept.

Just before spraying pesticides, all study spots were surrounded by PVC fence with the height of $1.2 \mathrm{~m}(20 \mathrm{~cm}$ higher than the height of the rice) to avoid contamination of pesticides from the next spots. The number of white heads and healthy stem were counted on $16^{\text {th }}$ October 2012. All hills in plots were cut off, and rice was dried till humidity of the grain reached $14 \%$, in order to assess the yield.

Statistical analyses were carried out using ANOVA. The percentages of white heads were calculated by Abbott formula (1925).

\section{RESULTS}

\section{Dynamics of larvae and pupae of YRSB in 2011 and 2012}

Tables 2 and 3 presented the density dynamics of YRSB larvae and pupae in rice paddies. During 2011 and 2012 , in both late spring and middle summer rices, the density of the larvae was consistently low. The highest densities in late spring rice were 0.27 and 0.40 larvae $/ \mathrm{m} 2$ in 2011 and 2012, respectively. For the middle summer rice crop, the highest densities of YRSB larvae were 0.67 and 2.53 larvae $/ \mathrm{m}^{2}$ in 2011 and 2012 , respectively. The peak of larval density in the late spring rice was at the stage of heading to milky, and that in the middle summer rice was the heading stage. In both years, the densities

Table 1. List of the treatments applied in the field experiments

\begin{tabular}{clll}
\hline TT & \multicolumn{1}{c}{ Treatment } & Dose & \multicolumn{1}{c}{ Group } \\
\hline 1 & I. Remove egg masses 2 times & & \\
2 & II. Remove egg masses 1 time and Regent 800 WG 1 spray & $56 \mathrm{~g} / \mathrm{ha}$ & \\
3 & III. Remove egg masses 1 time and Virtako 40 WG 1 spray & $83 \mathrm{~g} / \mathrm{ha}$ & \\
4 & IV. Remove egg masses 1 time and Prevathon 5 SC 1 spray & $417 \mathrm{ml} / \mathrm{ha}$ & \\
5 & V. Regent 800 WG 1 spray & $56 \mathrm{~g} / \mathrm{ha}$ & Fipronil \\
6 & VI. Virtako 40 WG 1 spray & $83 \mathrm{~g} / \mathrm{ha}$ & Chlorantraniliprole + thiamethoxam \\
7 & VII. Prevathon 5 SC 1 spray & $417 \mathrm{ml} / \mathrm{ha}$ & Chlorantraniliprole \\
8 & VIII. Regent 800 WG 2 sprays & $56 \mathrm{~g} / \mathrm{ha}$ & \\
9 & IX. Virtako 40 WG 2 sprays & $83 \mathrm{~g} / \mathrm{ha}$ & \\
10 & X. Prevathon 5 SC 2 sprays & $417 \mathrm{~mL} / \mathrm{ha}$ & \\
11 & XI. Control & - & \\
\hline
\end{tabular}


Table 2. The densities of larvae and pupae of yellow rice stem borer in late spring rice at Anlao, Haiphong Province, 2011 and 2012

\begin{tabular}{|c|c|c|c|c|c|c|c|}
\hline \multicolumn{5}{|c|}{ Late Spring Rice 2011} & \multicolumn{3}{|c|}{ Late Spring Rice 2012} \\
\hline Date & Rice stage & $\begin{array}{l}\text { Larval density } \\
\quad\left(\text { per } \mathrm{m}^{2}\right)\end{array}$ & $\begin{array}{l}\text { Pupal density } \\
\left.\text { (per } \mathrm{m}^{2}\right)\end{array}$ & Date & Rice stage & $\begin{array}{l}\text { Larval density } \\
\quad\left(\text { per } \mathrm{m}^{2}\right)\end{array}$ & $\begin{array}{l}\text { Pupal density } \\
\left.\text { (per } \mathrm{m}^{2}\right)\end{array}$ \\
\hline $22 / 3$ & Tillering & 0.00 & & $17 / 3$ & Tillering & 0.00 & \\
\hline $29 / 3$ & Tillering & 0.00 & & $24 / 3$ & Tillering & 0.00 & \\
\hline $5 / 4$ & Tillering & 0.00 & & $1 / 4$ & Tillering & 0.00 & \\
\hline $13 / 4$ & Tillering & 0.00 & & $8 / 4$ & Tillering & 0.13 & \\
\hline $19 / 4$ & Tillering & 0.13 & & $15 / 4$ & Tillering & 0.13 & 0.13 \\
\hline $26 / 4$ & Booting & 0.00 & & $21 / 4$ & Booting & 0.13 & \\
\hline $2 / 5$ & Booting & 0.00 & & $28 / 4$ & Booting & 0.13 & \\
\hline $10 / 5$ & Booting & 0.13 & & $5 / 5$ & Booting & 0.27 & \\
\hline $18 / 5$ & Heading & 0.13 & & $13 / 5$ & Heading & 0.40 & \\
\hline $24 / 5$ & Heading & 0.13 & 0.00 & $20 / 5$ & Heading & 0.27 & \\
\hline $31 / 5$ & Milky & 0.27 & 0.13 & $27 / 5$ & Milky & 0.13 & 0.13 \\
\hline $7 / 6$ & Dough & 0.00 & 0.27 & $2 / 6$ & Dough & 0.13 & 0.27 \\
\hline $14 / 6$ & Yellow ripe & 0.00 & 0.13 & $9 / 6$ & Yellow ripe & 0.00 & 0.13 \\
\hline
\end{tabular}

Table 3. The densities of larvae and pupae of yellow rice stem borer in middle summer rice at Anlao, Haiphong Province, 2011 and 2012

\begin{tabular}{|c|c|c|c|c|c|c|c|}
\hline \multicolumn{5}{|c|}{ Middle Summer Rice 2011} & \multicolumn{3}{|c|}{ Middle Summer Rice 2012} \\
\hline $\begin{array}{c}\text { Date } \\
\text { (Date/Month) }\end{array}$ & Rice stage & $\begin{array}{l}\text { Larval density } \\
\quad\left(\text { per } \mathrm{m}^{2}\right)\end{array}$ & $\begin{array}{l}\text { Pupal density } \\
\quad\left(\text { per } \mathrm{m}^{2}\right)\end{array}$ & $\begin{array}{c}\text { Date } \\
\text { (Date/Month) }\end{array}$ & Rice stage & $\begin{array}{l}\text { Larval density } \\
\quad\left(\text { per } \mathrm{m}^{2}\right)\end{array}$ & $\begin{array}{l}\text { Pupal density } \\
\left.\text { (per } \mathrm{m}^{2}\right)\end{array}$ \\
\hline $09 / 8$ & Tillering & - & & $07 / 08$ & Tillering & 0.67 & \\
\hline $16 / 8$ & Tillering & 0.13 & & $14 / 08$ & Tillering & 1.07 & 0.13 \\
\hline $23 / 8$ & Tillering & 0.40 & 0.13 & $21 / 08$ & Tillering & 1.20 & 0.27 \\
\hline $30 / 8$ & Tillering & 0.13 & & $28 / 08$ & Booting & 0.53 & \\
\hline $06 / 9$ & Booting & 0.27 & & $04 / 09$ & Booting & 1.47 & \\
\hline $13 / 9$ & Booting & 0.27 & & $11 / 09$ & Booting & 1.33 & \\
\hline $20 / 9$ & Booting & 0.27 & & $18 / 09$ & Heading & 2.53 & 0.27 \\
\hline $27 / 9$ & Heading & 0.67 & 0.13 & $25 / 09$ & Heading & 1.20 & 1.47 \\
\hline $04 / 10$ & Heading & 0.53 & 0.40 & $02 / 10$ & Milky & 0.67 & 0.80 \\
\hline $11 / 10$ & Milky & 0.27 & 0.53 & $09 / 10$ & Dough & 0.00 & 0.53 \\
\hline $18 / 10$ & Dough & 0.00 & 0.40 & $16 / 10$ & Yellow ripe & 0.00 & 0.00 \\
\hline $25 / 10$ & Yellow ripe & 0.00 & 0.13 & & & & \\
\hline
\end{tabular}

of YRSB pupae were lower than those of larvae. YRSB was obviously the second generation in the late spring crop (during the heading stage) and the fifth generation in the middle summer rice crop (heading to yellow ripe in 2011 and booting to yellow ripe in 2012).

\section{Damage caused by YRSB in 2011 and 2012}

The percentages of dead hearts or white heads detected during the field survey in 2011 and 2012 were summarized in Fig. 1. During four rice crop seasons in 2011 and 2012, low densities of YRSB larvae leaded to low dead hearts (\%) and low white heads (\%) for late spring and middle summer rices in 2011 and in 2012 (Fig. 1).

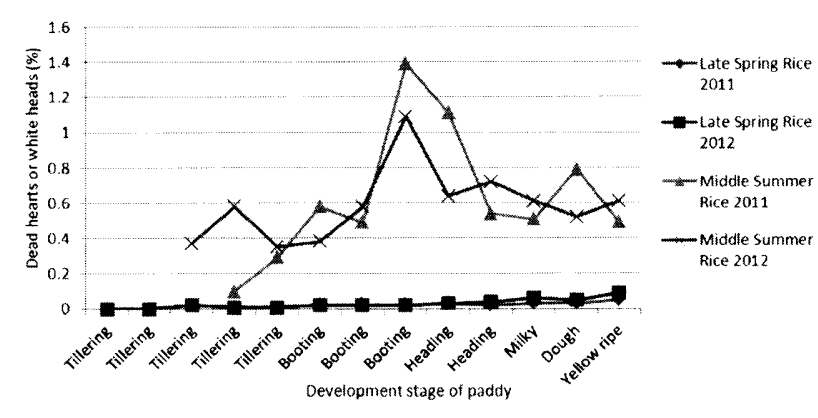

Fig. 1. Dead hearts and white heads (\%) in late spring and middle summer rices, 2011 and 2012. 
The percentages of dead hearts and white heads in late spring rice were lower than those in middle summer rice.

In both years, the highest percentages of dead hearts and white heads in late spring rice were recorded at the yellow ripe stage while those of middle summer rice were detected during the booting and heading stages.

\subsection{Efficacy of removal of egg mass and insecti- cides}

The results of the treatments for controlling of YRSB are presented in Table 3 . The results showed that all control measures such as removal of egg mass and spraying any of three insecticides provided better suppressions of YRSB than the control. Efficacy of different measures was assessed on the basis of the percentages of white heads, which were lower than the control. In treatments of spraying insecticides twice, the percentage of white heads was lower than spraying insecticides once. Regent $800 \mathrm{WG}$, an insecticide which has been used here for more than 10 years, provided lower efficacy than two newly used insecticides Virtako $40 \mathrm{WG}$ and Prevathon 5 SC did. The percentage of white heads was very low for the egg-mass removal group (1.8\%). Treatments with spraying Virtako 40 WG (VI) and Prevathon 5 SC (VII) and removal egg mass with spraying Virtako $40 \mathrm{WG}$ (III) and Prevathon 5 SC (IV) witnessed low percentage of white heads.

Next, we analyzed how crop yield could be affected by the insecticide treatments. The highest yield was obtained for the treatments spraying twice with Virtako $40 \mathrm{WG}$ (IX) and Prevathon 5 SC (X), removal egg mass 2 times (I), removal of egg mass and spraying 1 time Virtako 40 WG (III) and Prevathon 5 SC (IV) and spray 1 time Virtako $40 \mathrm{WG}$ (VI) and Prevathon 5 SC (VII), followed by removal of egg mass 1 time and spraying 1 time Regent 800 WG (II), spaying twice Regent 800 WG (VIII) and spraying 1 time Regent $800 \mathrm{WG}$ (V). The lowest yield was obtained at the control treatment (XI).
From the economic view, 4 treatments, i.e., spraying Virtako 470WG and Prevathon $5 \mathrm{SC}$ once or twice (VI, VII, IX and X) provided the highest effectiveness (with net profit higher than $7.0 \mathrm{VND}$ million/ha). Treatments (I) and (II) provided the lowest effectiveness (1.0-1.3 VND million/ha). Effectiveness of the other treatments was 3.2 to 3.7 VND million/ha.

\section{DISCUSSION}

During the last 15 years (1998-2012) in Haiphong, there is one important generation of YRSB in each ricegrowing season. It is the second generation for spring rice with the peak of adult emergence in May and the fifth generation for the middle summer crop with the peak adult emergence between early September and middle October.

The effective control measures have been based on the data obtained on the light traps and on investigation of larval and pupal densities in the field. In Haiphong, during 1970-1980, measures for controlling of YRSB were oil lamp traps to catch adults, egg mass removal by hand picking and pesticide spraying From 1990 onward, the use of oil lamps had been low because the electiricity became available in most rural areas and because attractiveness on YRSB adults of oil lamp traps was very low. The removal of egg masses by hand picking was still an option of control but done in a small scale, mainly in small fields for special quality rice and in long rain periods (4-7 days), which coincided the peak of adult appearance. During long time rain, all treatment measures provided very low efficacy. Pheromone traps become the only possible measure but up to now this measure is not applied. One attempt was conducted to test pheromone trap in 2008 in the study region but the efficacy was low due to high number of YRSB adults.

On average, farmers spray pesticides twice per crop right before and after the blossom period, mainly to

Table 4. The percentages of white head, efficacy and yield among different treatments in middle summer rice, 2012

\begin{tabular}{|c|c|c|c|c|c|}
\hline $\mathrm{TT}$ & Treatment & Dose & $\begin{array}{c}\text { White head } \\
\text { (\%) }\end{array}$ & $\begin{array}{l}\text { Efficacy of } \\
\text { treatments } \\
(\%)\end{array}$ & $\begin{array}{c}\text { Yields } \\
\text { (tones/ha) }\end{array}$ \\
\hline 1 & I. Remove egg masses 2 times & - & $1.7 \mathrm{~g}$ & 93.1 & $4.7 \mathrm{ab}$ \\
\hline 2 & II. Remove egg masses and Regent $800 \mathrm{WG}$ & $56 \mathrm{~g} / \mathrm{ha}$ & $9.0 \mathrm{~d}$ & 63.6 & $4.3 \mathrm{~b}$ \\
\hline 3 & III. Remove egg masses and Virtako $40 \mathrm{WG}$ & $83 \mathrm{~g} / \mathrm{ha}$ & $4.0 \mathrm{e}$ & 83.8 & $4.6 \mathrm{ab}$ \\
\hline 4 & IV. Remove egg masses and Prevathon 5 SC & $417 \mathrm{ml} / \mathrm{ha}$ & $3.8 \mathrm{e}$ & 84.6 & $4.6 \mathrm{ab}$ \\
\hline 5 & V. Regent $800 \mathrm{WG}$ & $56 \mathrm{~g} / \mathrm{ha}$ & $15.2 \mathrm{~b}$ & 38.5 & $4.1 \mathrm{~b}$ \\
\hline 6 & VI. Virtako $40 \mathrm{WG}$ & $83 \mathrm{~g} / \mathrm{ha}$ & $4.1 \mathrm{e}$ & 83.4 & $4.6 \mathrm{ab}$ \\
\hline 7 & VII. Prevathon $5 \mathrm{SC}$ & $417 \mathrm{ml} / \mathrm{ha}$ & $4.3 \mathrm{e}$ & 82.6 & $4.6 \mathrm{ab}$ \\
\hline 8 & VIII. Regent 800 WG 2 sprays & $56 \mathrm{~g} / \mathrm{ha} / 1$ spray & $11.7 \mathrm{c}$ & 52.6 & $4.2 \mathrm{~b}$ \\
\hline 9 & IX. Virtako 40 WG 2 sprays & $83 \mathrm{~g} / \mathrm{ha} / 1$ spray & $0.8 \mathrm{~h}$ & 96.8 & $4.8 \mathrm{a}$ \\
\hline 10 & X. Prevathon 5 SC 2 sprays & $417 \mathrm{ml} / \mathrm{ha} / 1$ spray & $0.9 \mathrm{~h}$ & 96.4 & $4.8 \mathrm{a}$ \\
\hline 11 & XI. Control & No treatment & $24.7 \mathrm{a}$ & 0.0 & $3.6 \mathrm{c}$ \\
\hline
\end{tabular}

*Means within a column followed by the same letter are not significantly different at 0.05 the level in an LSD test 
reduce white heads. The insecticides used are fipronil, cartap (nereistoxin), chlorpyrifos-ethyl, diazinon, and fenvalerate. In general, the monitoring of YRSB has been carried out by local plant protection technicians to assess the optimal timing of insecticide applications. Egg hatching time is recognized as an important factor determining the efficacy of insecticides.

In the past, reports of Ninh (1974), Cung (1974), Chinh (1977) and Quyen (2012) showed that YRSB was dominant compared to other three rice stem borers, i.e., Sesamia inferens Walker, Chilo polychrysa Meyrick and Chilo suppressalis Walker, in the RRD since 1970. In additipon, the percentages of YRSB occurrence have gradually increased from $0.5-20 \%$ (1954-1958), 42.8\% (1960), 63.6\% (1970), 98.5\% (1985), 98.8\% (1989) and $98.9 \%$ (1992), and YRSB is now the most important stem borers in rice.

Using improved rice varieties in increasingly large area with blossom time in hot suitable time (for spring rice May 5-May 20 and for summer rice Sept. 15-Sept. 20 ) is suitable for development of YRSB. The change of crop time is one of the key reasons for dominance of YRSB. A significant fact on this to be mentioned was percentage YRSB eggs parasitized in 2011 and 2012 was not different with those during 1998-2011 (Plant Protection Dept. of Haiphong, 2012).

Quyen (2012) determined the lowest temperatures for development of YRSB for all four developmental phases (egg, larva, pupa and adult) and they were $16.6^{\circ} \mathrm{C}$, $15.2^{\circ} \mathrm{C}, 16.5^{\circ} \mathrm{C}$ and $16.0^{\circ} \mathrm{C}$, respectively. Based on the data, for the last 40 years, there should be 6 generations of YRSB in each year. The appearance of adults of the first generation is depended on the temperatures but it is mostly during December and January.

In Haiphong as well as in the RRD, in 3 years from 2009 to 2011, the temperatures from January to March, the spring rice season, were different from the averages of these months in the last 40 years. In 2009, temperatures of January and February were $4.5^{\circ} \mathrm{C}$ higher than the averages for last 40 years whereas temperatures of February and March in 2010 were $2.7^{\circ} \mathrm{C}$ lower. In addition, at the beginning of March, there was long coldness, causing development of the rice plant was 20-30 days longer than the other years, and the blossom period was in May 20 to 30, which did not coincide the peak of YRSB adul emergence. The damage caused by YRSB was consequently very low in that year. In fact, the density of YRSB in 2010 was lowest within the last 15 years (19982012). In 2011 and 2012, the YRSB gradually increased but YRSB densities were categorized in years with low YRSB during the last 15 years. In fact, YRSB densities given in the present study are generally low. Nevertheless, effective control measures are needed because there are a trend of YRSB being increasing and because the damage is serious if their incidence is higher.

Although an important progress in controlling of YRSB is application of sex pheromone traps in India and other Southern Asian countries (Cork, 1998; Cork et al., 2008), use of insecticides is a major option for YRSB management in most Asian countries, and new insecticides have been introduced. In Pakistan, Bhutto and Soomro (2010) tested efficacy of different emulsifiable concentration (EC) of 5 insecticides Karate, Thiodan, Boxer, Curator and Rogor, and demonstrated that Karate 2.5 EC provided highest efficacy, followed by Thiodan 35 EC.

In Haiphong, in heading stage of the rice, it has been recommended to spray when the density of egg masses is beyond 0.3 egg mass per $\mathrm{m}^{2}$. In addition, the second spray has been recommended when the density of egg masses is beyond 1 egg mass/ $\mathrm{m}^{2}$ after to keep the percentage of white heads under $5 \%$. Based on this standard, the treatments I, III, IV, VI, VII, IX and X are found to provide good control. Among the treatments tests, the treatment IX and X can keep the percentage of white heads lowest.

Although the treatment (I), removal of egg mass twice, resulted in low white head percentages, this measure, in practice, should be difficult to apply because every household has rice fields of more than $1500 \mathrm{~m}^{2}$ and because the removal of egg mass needs time and skill to detect the egg masses on the leaves. Thus, we conclude that use of Virtako $40 \mathrm{WG}$ and/or Prevathon $5 \mathrm{SC}$ should be of the highest economic effectiveness.

\section{ACKNOWLEDGEMENT}

We thank Mr. Hoang Van Dat, Do V. Sinh, and Ms. Nguyen T. N. Nga for their assistance of the field works. This study was supported in part by a Grant-in-Aid from the Vietnam National Foundation for Science and Technology Development (NAFOSTED) No106.11.183.09 and also by a Grant-in-Aid for Scientific Research (B), Japan No 24405028.

\section{REFERENCES}

Abbott, W. S. 1925 A method for computering the effectiveness of insecticides. J. Econ. Ent., 18: 265-267

Bhutto, A. A. and M. N. Soomro 2010 Efficacy of different emulsifiable concentration (EC) insecticides to control Yellow rice stem borer Scirpophaga incertulas (Walker) under field condition. J. Basic \& Appl. Sci., 6: 51-54

Chinh. N. M. 1977 Report on incidence and development of rice stem borers in Cole (Hanamninh) 1960-1974. Bull. Plant Prot., 2: 16-25

Cork. A. 1998 Pheromones for control of yellow stem borer in India: Does mating disruption meet the needs of the rice the cultivator? Proceedings of the Sixth Australasian Applied Entomological Research Conference. 29 Sept.-2 Oct. 1998, Brisbane, pp. 304-313

Cork A., K. de Souza. D. R. Hall, O. T. Jones, E. Casagrande, K. Krishnaiah, and Z. Syet 2008 Development of PVC-ResinControl release formulation for pheromones and use in disruption of yellow stem borer Scirpophaga incertulas. Crop Prot., 27: 248-255

Cung, N. X. 1974 Some features of incidence and damage of rice stem borers in North Vietnam. Bull. Plant Prot., 14: 15-26

Dinh, N. V. and B. S. Doanh 2010 A significant change of composition of rice pests and diseases within last 30 years (19752005). Procceedings of 3 rd National Plant Protection Conference, Hochiminh City. 16-17/8/2010, pp. 237-245

MARD 2010 National technical regulation on Surveillance method of plant pests. Agricultural Press, Hanoi

Ninh, V. D. 1974 Remarks on incidence of rice stem borers in winter spring and summer rice. Bull. Plant Prot., 16: 17-26 
Plant Protection Dept Haiphong 2012 Incidence of pests and diseases and their control 1997-2011. Annual Reports, Hanoi

Quyen, P. B. 2012 Yellow rice stem borer (Tryporyza incertulas Walker) and their natural enemies. In "Insects and Animals
Injurious to Agriculture of Vietnam", ed. by N. V. Dinh, H. Q. Hung, N. T. T. Cuc and P. V. Lam, Agricultural Press, Hanoi, pp. $541-552$ 